\title{
Editorials
}

\section{Pre-emptive analgesia: importance of timing}

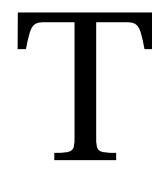

H E management of acute postoperative pain has been dominated by an outdated conceptualization of pain. ${ }^{1}$ Pain is viewed as the end-product of a passive transmission system that faithfully transmits a peripheral signal to the spinal cord and on up to a pain centre in the brain. This view has led to an approach of managing postoperative pain that does not provide adequate control of pain, in part, because it focuses on treating the patient only after the pain is well entrenched. Patients are transported to the recovery room after surgery, often in agonizing pain, where they then receive incremental doses of opioids in an attempt to reduce already established pain. However, basic science and clinical data show that brief, noxious inputs or frank injury due to $\mathrm{C}$-fibre activation (e.g., cutting tissue, nerve, and bone) induce long-lasting changes in central neural function that persist after the offending stimulus has been removed or the injury has healed. ${ }^{2}$ The recognition that the processes involved in pain perception involve a dynamic interplay between peripheral and central mechanisms is inconsistent with the simplistic notion that pain results from transmission of impulses along a straight-through pathway from the site of injury to the brain.

The practice of treating pain only after it has been established is slowly being supplanted by a preventive approach. The idea behind pre-emptive analgesia is not simply that it reduces nociception and stress during surgery - although these are obviously worthwhile goals. The hypothesis is that the transmission of noxious afferent input from the periphery (e.g., brought about by incision and subsequent noxious intraoperative events) to the spinal cord induces a prolonged state of central neural sensitization or hyperexcitability that amplifies subsequent input from the wound and leads to heightened postoperative pain. By interrupting the transmission of noxious peri-operative inputs to the spinal cord, a pre-emptive approach can prevent the establishment of central sensitization, resulting in reduced pain intensity and lower analgesic requirements even after the analgesic effects of the (pre-emptive) agents have worn off. ${ }^{3}$

Although recent reviews ${ }^{4,5}$ have highlighted inconsistent outcomes in clinical studies of pre-emptive analgesia, the controversy extends beyond the issue of efficacy. M ore fundamentally, it involves the very definition of the phenomenon. ${ }^{6,7} \mathrm{~N}$ ot surprisingly, confusion over the appropriate definition has contributed to the controversy over efficacy. This has been partially resolved by the view that the term pre-emptive analgesia can be defined in a broad (pre-surgical analgesic administration vs no treatment or placebo treatment) or narrow (pre-surgical vs post-surgical analgesic administration) sense. ${ }^{5}$

Targets of Pre-emptive Analgesia

From a conceptual point of view, the perioperative period can be divided into three fairly distinct phases: preoperative, intraoperative, and postoperative. The role of certain factors within these three phases (as well as the interaction among factors) contributes to the development of acute postoperative pain. These factors include: (1) preoperative noxious inputs and pain, (2) noxious intraoperative inputs arising from the cutting of skin, muscle, nerve and bone, wound retraction, etc., and, (3) postoperative noxious inputs including those arising from the inflammatory response and ectopic neural activity in the case of postsurgical nerve injury. Each of these factors can contribute both to peripheral and central sensitization and each is a legitimate target for a pre-emptive analgesic approach. The relative contribution of these three factors to acute postoperative pain is dependent on the surgical procedure, extent and nature of tissue damage, duration of surgery, timing of pre-emptive treatment relative to incision, pharmacokinetics of the agent(s) used pre-emptively, presence or absence of 
additional analgesia intraoperatively, nature of postoperative analgesia, and a host of other variables. $M$ inimizing the impact of as many of these factors in the three phases will increase the likelihood of preventing the induction and maintenance of peripheral and central sensitization. Preventing sensitization will reduce pain and analgesic requirements.

\section{Recent Progress in Pre-emptive Analgesia}

The possibility that pain after surgery might be amplified by the noxious events induced by surgical incision was initially put forward by $\mathrm{Crile}^{8}$ and more recently by Wall ${ }^{9}$ who coined the term "preemptive preoperative analgesia". Wall suggested that administration of opioids and/ or local anesthetics before surgery might reduce the central (spinal) neural effects of the C-fibre induced injury barrage associated with incision and thereby reduce postoperative pain intensity. Since then it has been documented that although general anesthesia may attenuate the transmission of noxious afferent informa tion from the periphery to the spinal cord and brain, it does not block it. ${ }^{10,11} \mathrm{M}$ oreover, it appears that systemic opioids may not provide a sufficiently dense blockade of spinal nociceptive neurons to prevent central sensitiza tion. ${ }^{12}$ The clinical importance of these findings for patients that receive general anesthesia during surgery is that while they are unconscious, the processes leading to sensitization of dorsal horn neurons are unaffected by the general anesthesia or routine doses of opioids. This sets the stage for increased post-surgical pain and an increased requirement for analgesics.

Since its introduction into the anesthesia literature, the concept of pre-emptive analgesia has evolved, based in part on confirmatory and contradictory evidence from clinical studies, new developments in basic science, and critical thought. This evolution has led to progress in our understanding of the mechanisms that contribute to acute postoperative pain. The suggestion that surgical incision triggered central sensitization has been expanded to include the sensitizing effects of preoperative noxious inputs and pain, other noxious intraoperative stimuli as well as postoperative inflammatory mediators and ectopic neural activity. Similarly, as knowledge has emerged describing the mechanisms underlying central senstization, agents other than those proposed by Wall have been evaluated in an effort to pre-empt postoperative pain (e.g., NDM A antagonists, N SAID S, alpha- ${ }_{2}$ agonists).

Pre-emptive Analgesia and N on-Steroidal AntiInflammatory Agents

In the present issue, $\mathrm{O}^{\prime} \mathrm{H}$ anlon et al. ${ }^{13}$ compared administration of $20 \mathrm{mg}$ tenoxicam iv $30 \mathrm{~min}$ before ambulatory breast biopsy with administration of the same dose at induction of anaesthesia (approximately five to ten minutes before incision). The study was randomized and single-blind but not placebo-controlled (i.e., not double dummy). All patients received $5 \mu \mathrm{g} \cdot \mathrm{kg}^{-1}$ alfentanil at induction of the general anesthetic as well as subcutaneous wound infiltration with $10 \mathrm{ml}$ bupivacaine $0.5 \%$ at the end of surgery but prior to emergence. Pain and analgesic consumption were measured after surgery at regular intervals for a fourhour period. The results showed a striking advantage for patients who received the tenoxicam $30 \mathrm{~min}$ before surgery. Time to first request for postoperative analgesics was longer, total doses of demerol and diclofenac were lower, and fewer patients required additional analgesia. Visual analogue pain scores were lower at all time points $(30,60,120$, and $240 \mathrm{~min})$ across the four-hour period.

The results of the study by $\mathrm{O}^{\prime} \mathrm{H}$ anlon et al. ${ }^{13}$ have implications for the mechanisms by which pre-emptive analgesia exerts its effects. The results also contribute to the debate over the efficacy of pre-emptive analgesia. The analgesic effects of N SAID s have been attributed to their peripheral anti-inflammatory actions in inhibiting the synthesis of prostaglandins through the inactivation of cyclooxygenase. ${ }^{14}$ This effect is an indirect one in that prostaglandins themselves do not produce pain but sensitize receptors at the site of injury to a variety of neurochemicals (e.g., bradykinin, serotinin, SP, CGRP). Thus, at least insofar as their peripheral effects are concerned, NSAIDs are more accurately anti-hyperalgesic than analgesic in action. $O$ bservations that the anti-inflammatory and analgesic effects of N SAID s could be dissociated raised the possibility of a central site of action for these agents. ${ }^{14}$ The spinal effects of NSAIDs are not as well documented, but include the possibility of a non-antiinflammatory analgesic action brought about by the inhibition of cyclooxygenase in the spinal cord and a consequent reduction in spinal NMDA-mediated events. ${ }^{14,15}$

When administered prior to injury, opioid agonists and local anesthestics prevent central sensitization by attenuating nociceptive processing and blocking nerve conduction, respectively. In contrast, the pre-emptive analgesic effects of NSAIDs arise by attenuating the inflammatory response thereby reducing peripheral sensitization and its effects on spinal nociceptive processing, including the induction and maintenance of central sensitization. In addition to this peripheral mechanism, the central actions of N SAID s may also contribute to a pre-emptive analgesic effect by preventing spinal prostanoid synthesis thus reducing pre- 
and post-synaptic release of neurotransmitter (e.g. neuropeptides and EAAs) from primary afferent terminals and spinal interneurons. The net effect of both actions would be to prevent or considerably attenuate development of a hyperexcitable state in spinal cord dorsal horn neurons. In terms of the patient's experience of pain after surgery, this would translate into less intense pain and a reduced requirement for postoperative analgesics. This indicates that N SAID s may preempt different components of postoperative pain (e.g., central and peripheral sensitization) by more than one mechanism.

From the standpoint of efficacy, the magnitude of the effects observed by $\mathrm{O}^{\prime} \mathrm{H}$ anlon et al. ${ }^{13}$ are clinically important. As noted below, however, this is contrary to the majority of studies that have used N SAID s to pre-empt postoperative pain. Cumulative consumption of demerol and diclofenac were reduced by $87 \%$ and $50 \%$, respectively and at the same time, the average difference in VAS pain scores was almost $1.5 \mathrm{~cm}$. These results are especially impressive when one considers that the main difference between the groups was the timing of administration of tenoxicam relative to incision with one group receiving the NSAID approximately 20 min before the other. The study design is novel in that both groups received the tenoxicam pre-operatively. The 20 min difference in time of administration conferred a benefit that persisted for at least four hours after surgery.

These results are not what would be expected if pain were simply the end result of a passive transmission system from periphery to brain. Based on what is known about the pharmacokinetics of tenoxicam, ${ }^{16}$ one might have expected the distribution of pain scores and analgesic consumption to be identical for the two groups beginning at the initial pain assessment 30 min after surgery and extending across the four hour study period. The 30-min time point corresponded to approximately 78 and 58 min after administration of the tenoxicam (to the two groups), indicating sufficient time had elapsed for the drug to have reached peak effect. Although the authors report only total consumption of analgesics and do not provide data showing the pattern of analgesic consumption over the four hour period, it is likely that by the 30 min pain assessment, patients in both groups had yet to request or receive rescue pain medication. This assumption is based on a lower limit for the $99 \%$ confidence interval of 74 and 44 min respectively for the two groups in the time to first request for analgesics (calculated from data in Table I). ${ }^{13}$ Thus, as early as 30 min after surgery, before rescue analgesia had been administered, the mean difference in pain scores was
$2.3 \mathrm{~cm}$. The maintenance of a difference in pain over the four hour period coupled with the lower consumption of analgesics is strong evidence of a preemptive analgesic effect.

$\mathrm{H}$ ow do the results of the $\mathrm{O}^{\prime} \mathrm{H}$ anlon et al. ${ }^{13}$ study compare with those of other studies that administered NSAIDs to pre-empt postoperative pain? Of the 18 randomized, single- or double-blind studies that used an NSAID as the target intervention, five evaluated broad pre-emptive effects, ${ }^{17-21}$ nine evaluated narrow pre-emptive effects, ${ }^{13,22-29}$ and four both broad and narrow effects. ${ }^{30-33}$ Studies of patients undergoing oral surgery such as third molar extraction 17,18,20,22-25 or pulpectomy ${ }^{30}$ were among the earliest to be conducted. More recently, other procedures have been studied, including abdominal hysterectomy, ${ }^{26,33}$ orthopedic surgery, ${ }^{21,27,28,31,32}$ laparoscopy, ${ }^{19}$ and breast biopsy. ${ }^{13,29}$ Routes of administration include oral, rectal, intramuscular and intravenous. A variety of NSAIDS have been used including the propionic acids, acetic acids, oxicams and paracetamol that differ in the extent of their anti-inflammatory activity, analgesic effects, antipyretic actions and pharmacokinetics.

$O$ verall, the results have not been encouraging. Pre-emptive analgesic effects were reported by six studies ( $\sim 33 \%)$; three ( $16.5 \%)$ of which found narrow effects ${ }^{13,29,32}$ and three $(\sim 16.5 \%)$, broad effects. ${ }^{17,30,31} \mathrm{~N}$ ot only is the proportion of positive studies small, but the magnitude of the effects, when present, is modest at best. The one exception to this is a randomized study ${ }^{29}$ conducted at the same institution as the study by $\mathrm{O}^{\prime} \mathrm{H}$ anlon et al. ${ }^{13}$ in which $20 \mathrm{mg}$ tenoxicam iv was administered to women undergoing breast biopsy either 30 min before surgery or an unspecified period of time after incision. Patients in the pre-emptive tenoxicam group took longer to request postoperative analgesics, required less meperidine and reported lower pain scores over the four hour observation period. The magnitude of these effects equaled that of the study by $\mathrm{O}^{\prime} \mathrm{H}$ anlon et al. ${ }^{13}$ Inspection of the data from the two studies ${ }^{13,29}$ suggests that administration of tenoxicam at induction represents too late a pre-surgical intervention to capitalize on a pre-emptive analgesic effect and offers no advantage over post-incision administration.

In general, the ability to demonstrate pre-emptive analgesic effects using NSAIDs (vs opioids or local anesthetics) is made more difficult because these agents do not block nociceptive processing or nerve conduction. As a consequence, clinical studies are inevitably confounded by the co-administration of systemic opioids and/ or a local anesthetic infiltration to all patients in order to provide sufficient analgesia or 


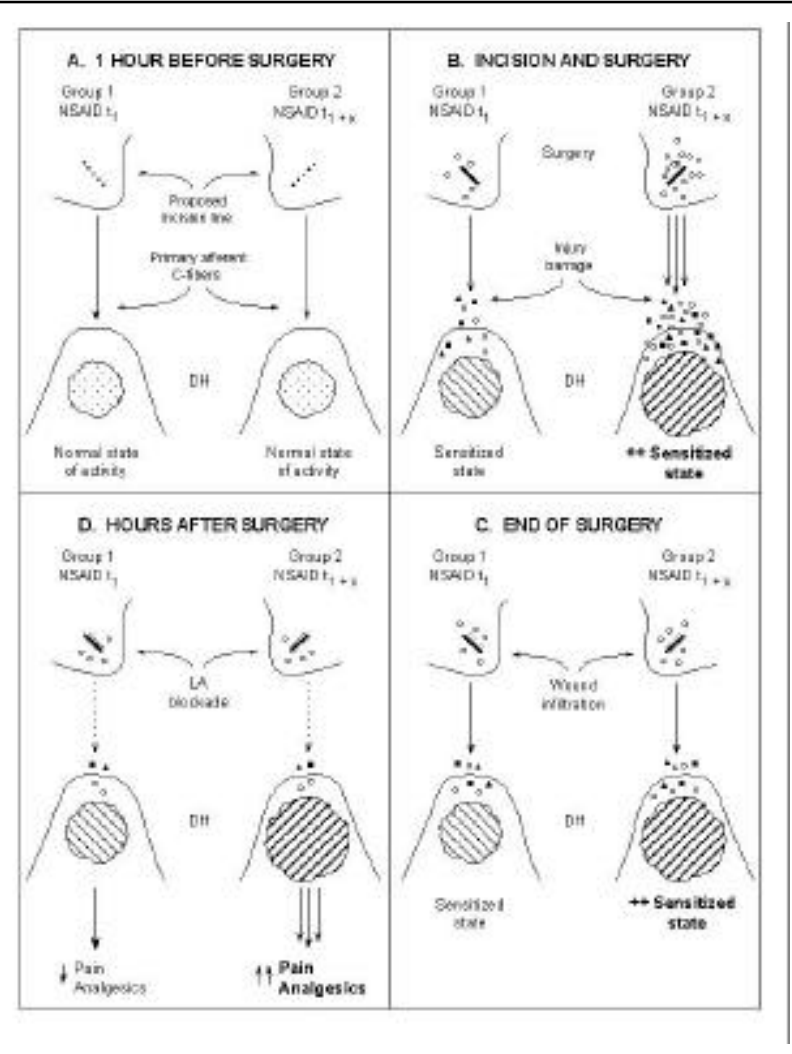

FI GU RE Schematic model of a 2-group study of pre-emptive analgesia using an N SAID as the target intervention combined with postoperative local anaesthestic wound infiltration. Time 1 $\left(t_{1}\right)$ corresponds to time of administration of the NSAID relative to incision for group 1. $t_{1+x}$ corresponds to time of administration for group 2. In the study by $\mathrm{O}^{\prime} \mathrm{H}$ anlon et al., $\mathrm{t}_{1}=-30 \mathrm{~min}$; $\mathrm{t}_{1+\mathrm{x}}=$ $\sim 10 \mathrm{~min}$. A. O ne hour before surgery prior to any anaesthetic intervention, showing periphery and dorsal horn (DH ) in states of normal activity. B. Incision and subsequent noxious surgical events induce inflammation-mediated peripheral sensitization and central sensitization from injury barrage. Filled triangles and squares represent neuropeptides (e.g., substance $P(S P)$ ) and excitatory amino acids (EAAs; e.g., glutamate) co-released from $\mathrm{C}$-fibre terminals in response to surgery. O pen circles represent prostaglandins released at the site of injury and in the spinal cord. Spinal prostanoids may diffuse into the extracellular space and enhance $C$-fibre release of SP and EAA by a calcium-dependent mechanism. Timing of tenoxicam administration results in a relative reduction of both peripheral and central sensitization in group 1 compared with group 2. C. By the time of wound infiltration with bupivacaine, tenoxicam has resulted in a reduction of prostanoid release in both groups, but relative states of sensitization induced by surgical trauma are maintained. D. In the hours after surgery, the combined actions of tenoxicam (inhibition of cyclooxygenase cascade) and bupivacaine (nerve conduction block) reduce transmission to $\mathrm{DH}$ neurons thereby preventing further sensitization. The net effect of the heightened states of sensitization in group 2 is to amplify the peripheral and central signals leading to greater pain and an increase in postoperative analgesic requirements relative to group 1. N ote that the neurochemical events depicting the peripheral and central processes that transpire following injury have been simplified. anesthesia during the surgical procedure. This would have the unintended effect of pre-empting pain in the control group thus minimizing the inter-group differences in pain and analgesic consumption.

In the study by $\mathrm{O}^{\prime} \mathrm{H}$ anlon et al., ${ }^{13}$ administration of alfentanil may have contributed to a pre-emptive analgesic effect in both groups by reducing the flow of noxious afferent transmission to the spinal cord during surgery. Pre-emptive effects of low dose systemic alfentanil administered intraoperatively have been demonstrated to persist for up to six hours after surgery 12 (but see ${ }^{34,35}$ ). More importantly, wound infiltration with bupivacaine, in combination with the tenoxicam likely reduced the amount and nature of afferent input reaching the spinal cord during the four hour period of observation. This intervention, in combination with the pre-operative tenoxicam, contributed to the impressive differences in pain and analgesic consumption (Figure 1 ). In other studies, failure to demonstrate a pre-emptive analgesic effect has been attributed to an inflammation-induced state of central sensitization that develops shortly after surgery, once the pharmacological action of the preoperative agent has worn off, or to insufficient afferent blockade in the postoperative period. ${ }^{36}$ This $\mathrm{H}$ ydra problem, ${ }^{37}$ so named after the mythical nineheaded serpent that would sprout two heads whenever one of the nine was cut off, has provided the impetus for using agents whose duration of action extends well into the postoperative period. ${ }^{38} \mathrm{In}$ the study by $\mathrm{O}^{\prime} \mathrm{H}$ anlon et al., ${ }^{13}$ the reduction in peripheral nociceptor activity and inflammation brought about by the combined actions of bupivacaine wound infiltration and preoperative iv tenoxcam appear to have been sufficient to inhibit further sensitization in the early postoperative period. This would have the effect of unmasking the greater relative state of central sensitization induced by incision and subsequent noxious intraoperative stimuli in the group that received the tenoxicam at induction (Figure 1). It is interesting to note that only two studies ${ }^{13,29}$ have combined preoperative administration of an N SAID with postoperative local anesthetic wound infiltration and both have demonstrated noteworthy reductions in pain and analgesic use.

Together, these results ${ }^{13,29}$ stand in stark contrast to the lack of clinically significant effects found by other studies in which N SAID s are used to pre-empt postoperative pain. That injury induces peripheral and central sensitization is well-established. So too is the ability of NSAIDs to prevent or reverse these abnormal states. $\mathrm{O}^{\prime} \mathrm{H}$ anlon et al. ${ }^{13}$ seem to have hit upon the right combination of factors to demonstrate a pre- 
emptive analgesic effect; namely, pre-operative iv tenoxicam, a procedure of short duration, tissue damage transmitted mainly by somatic afferent fibres, post-surgical infiltration using a long-acting local anesthetic agent, and assessment of pain and analgesic consumption in the early postoperative period.

Acknowledgments

Supported by grants M CT-38144 and M O P-37845 from the Canadian Institutes of $\mathrm{H}$ ealth Research $(\mathrm{CIHR})$ and $\mathrm{a} \mathrm{CIHR}$ Investigator A ward.

\section{L'analgésie préventive : choisir le bon moment}

Le traitement de la douleur postopératoire aiguë a été dominé par une conceptualisation périmée de la douleur. ${ }^{1} \mathrm{O} n$ a considéré la douleur comme le dernier élément d'un système de transmission passive qui achemine un signal de la périphérie à la moelle épinière, puis au centre cérébral de la douleur. Cette vision nous a amenés à traiter la douleur postopératoire d'une manière qui ne pouvait en assurer le contrôle adéquat, en partie, parce que l'accent était mis sur le fait de traiter seulement après que la douleur s'est bien installée. Après I'opération, les patients sont transportés à la salle de réveil, souvent très souffrants, et ils reçoivent alors des doses progressives d'o pioïdes. Cependant, la science fondamentale et les données cliniques montrent que de brefs stimuli nuisibles ou une lésion franche liée à l'activation des fibres $C$ (par la section de tissus, de nerfs ou d'os) induisent des changements de la fonction nerveuse centrale qui persistent même après que le stimulus en cause a été retiré ou que la blessure a été guérie. ${ }^{2} \mathrm{~L}$ a reconnaissance des mécanismes impliqués dans la perception de la douleur comme étant l'interaction dynamique entre les systèmes nerveux périphérique et central diffère donc de la notion simpliste de la douleur comme le résultat de la transmission des impulsions directement du site de la lésion vers le cerveau.

Petit à petit, c'est par une démarche préventive qu'on tend à remplacer la pratique qui consistait à traiter la douleur seulement une fois installée. L'idée qui sous-tend l'analgésie préventive n'est pas simplement de réduire la nociception et le stress pendant I'intervention chirurgicale, ces motifs étant, évidemment, valables. L'hypothèse veut que la transmission d'un stimulus afférent nuisible provenant de la périphérie (par exemple, de l'incision et d'interventions peropératoires nocives subséquentes), allant vers la moelle épinière, induise un état prolongé de sensibilisation nerveuse centrale ou d'hyperexcitabilité qui amplifie le stimulus provenant ensuite de la plaie et provoque une intensification de la douleur postopératoire. En interrompant la transmission des stimuli périopératoires nuisibles vers la moelle épinière, une démarche préventive peut empêcher l'établissement de la sensibilisation centrale, ce qui a pour résultat de réduire l'intensité de la douleur et de diminuer les besoins analgésiques même après que les effets analgésiques des agents préventifs ont cessé de faire effet. ${ }^{3}$

$M$ ême si de récentes révisions ${ }^{4,5}$ ont mis en relief les résultats contradictoires d'études cliniques sur l'analgésie préventive, la controverse s'étend au delà de l'efficacité. Elle implique, plus précisément, la définition même du phénomène. ${ }^{6,7}$ Comme on pouvait $s^{\prime} y$ attendre, la confusion autour de la définition appropriée a contribué aux discussions sur l'efficacité. La question a été résolue en partie par l'idée que le terme d'analgésie préventive peut avoir une définition large (l'administration préchirurgicale d'un analgésique vsl'absence de traitement ou un placebo) ou stricte (l'administration préchirurgicale vs postchirurgicale d'un analgésique). ${ }^{5}$

\section{Les cibles de l'analgésie préventive}

Au plan conceptuel, la période périopératoire peut être divisée en trois phases relativement distinctes : préopératoire, peropératoire et postopératoire. Le rôle joué par certains facteurs à l'intérieur de ces trois phases (ainsi que l'interaction entre ces facteurs) contribue au développement de la douleur postopératoire aiguë. Ces facteurs comprennent : (1) des stimuli préopératoires nocifs et de la douleur, (2) des stimuli peropératoires nocifs provoqués par la section de tissu cutané, musculaire, nerveux et osseux, par la rétraction de la plaie, etc. et (3) des stimuli postopératoires nocifs incluant ceux qui sont causés par la réponse inflammatoire et l'activité neurale ectopique dans le cas de lésion nerveuse postchirurgicale. Chacun de ces facteurs peut contribuer à la sensibilisation périphérique autant que centrale et chacun constitue une cible justifiée de la méthode d'analgésie préventive. La contribution relative de ces trois facteurs à la douleur postopératoire dépend du procédé chirurgical, de l'étendue et de la nature de la lésion tissulaire, de la durée de l'o pération, du chronométrage du traitement préventif en regard de l'incision, de la pharmacocinétique des médicaments utilisés comme prévention, de la présence ou non d'analgésie peropératoire supplémentaire, de la 
nature de I'analgésie postopératoire et d'une foule d'autres variables. La réduction de l'impact d'autant de facteurs, pendant les trois phases, augmentera la possibilité de prévenir l'induction et le maintien de la sensibilisation périphérique et centrale. Empêcher la sensibilisation de se développer diminue la douleur et les besoins d'analgésiques.

\section{Évolution récente de l'analgésie préventive}

L a possibilité que la douleur postopératoire puisse être amplifiée par des stimuli nocifs induits par l'incision chirurgicale a été avancée d'abord par $\mathrm{Crile}^{8}$ et, plus récemment, par Wall ${ }^{9}$ qui a créé le terme "analgésie préopératoire préventive". Wall a suggéré que l'administration d'opioïdes et/ ou d'anesthésiques locaux avant l'opération pouvait réduire les effets, au niveau du système nerveux central (rachidien), de la charge lésionnelle induite par les fibres $C$ et associée à l'incision et, pouvait diminuer ainsi l'intensité de la douleur postopératoire. Depuis, on a prouvé que même si l'anesthésie générale peut atténuer la transmission d'informations afférentes nuisibles provenant de la périphérie vers la moelle épinière et le cerveau, elle ne les bloque pas. ${ }^{10,11} \mathrm{Q}$ ui plus est, il semble que les opioïdes à action générale ne fournissent peut-être pas un blocage suffisamment dense des neurones nociceptifs rachidiens pour empêcher la sensibilisation centrale. ${ }^{12}$ La portée clinique de ces découvertes dans les cas d'anesthésie générale est que, pendant la phase d'inconscience, le processus conduisant à la sensibilisation des neurones de la corne supérieure n'est pas affecté par l'anesthésie générale ou les doses habituelles d'opioïdes. Ce qui prépare à une douleur postchirurgicale accrue et à une plus grande demande d'analgésiques.

$D$ epuis son introduction dans la documentation sur l'anesthésie, le concept d'analgésie préventive a évolué, en partie à cause de l'évidence confirmée et contradictoire des études cliniques, de l'évolution de la science fondamentale et de l'esprit critique. Cette situation a fait progresser notre compréhension des mécanismes impliqués dans la douleur postopératoire. L'idée que l'incision chirurgicale déclenche une sensibilisation centrale s'est élargie et comprend les effets sensibilisateurs des stimuli nuisibles et de la douleur préopératoires, d'autres stimuli peropératoires nuisibles ainsi que l'activité des médiateurs de l'inflammation postopératoire et l'activité neurale ectopique. De même, à mesure que les connaissances qui s'élaborent décrivent les mécanismes sous-jacents à la sensibilisation centrale, des médicaments différents de ceux que Wall propose ont été évalués dans le but de prévenir la douleur postopératoire (par exemple, les antagonistes du N MDA, les AIN S, les agonistes alpha-2).
L'analgésie préventive et les anti-inflammatoires non stéroïdiens

$\mathrm{D}$ ans le présent numéro, $\mathrm{O}^{\prime} \mathrm{H}$ anlon et coll. ${ }^{13}$ rapportent avoir comparé l'administration iv de $20 \mathrm{mg}$ de ténoxicam, 30 min avant la biopsie du sein, avec l'administration d'une dose identique à l'induction de I'anesthésie (environ cinq à dix minutes avant l'incision). L'étude était randomisée et à l'insu mais non contrôlé par placebo, c'est-à-dire non à double feinte. Toutes les patientes ont reçu $5 \mu \mathrm{g} \cdot \mathrm{kg}^{-1}$ d'alfentanil à l'induction de l'anesthésie générale ainsi qu'une infiltration sous-cutanée de la plaie chirurgicale avec $10 \mathrm{ml}$ de bupivacaïne à $0,5 \%$ à la fin de l'opération, mais avant le retour à la conscience. La douleur et la consommation d'analgésique ont été mesurées après l'intervention à intervalles réguliers pendant quatre heures. Les résultats montrent un avantage frappant pour les patientes qui ont reçu le ténoxicam $30 \mathrm{~min}$ avant I'opération. Le temps écoulé avant la première demande d'analgésiques postopératoires a été plus long, les doses totales de démérol et de diclofénac ont été plus faibles et peu de patientes ont demandé de l'analgésie supplémentaire. Les scores à l'échelle visuelle analogique ont été plus bas pour toutes les mesures $(30,60,120$ et $240 \mathrm{~min})$ pendant les quatre heures d'évaluation.

Les résultats de l'étude de $\mathrm{O}$ ' $\mathrm{H}$ anlon et coll. ${ }^{13}$ modifient notre compréhension des mécanismes par lesquels I'analgésie préventive exerce son action. Ils contribuent également au débat sur l'efficacité de I'analgésie préventive. Les effets analgésiques des AIN S ont été attribués à leurs actions anti-inflammatoires périphériques qui sont d'inhiber la synthèse des prostaglandines par l'inactivation de la cyclooxygénase. ${ }^{14}$ Ces effets sont indirects, puisque les prostaglandines elles-mêmes ne produisent pas la douleur mais sensibilisent les récepteurs au site de la lésion à une variété de substances neurochimiques (comme la bradykinine, la sérotonine, les protéines plasmatiques PP, les peptides liés au gène de la calcitonine PLGC). Par conséquent, au moins dans la mesure où leur effet périphérique est concerné, les AINS ont une action plus précisément anti-hyperalgésique qu'analgésique. L'observation d'une dissociation possible des effets anti-inflammatoires et analgésiques des AINS soulève I'hypothèse d'un site d'action central de ces agents. Les effets rachidiens des AIN S ne sont pas bien connus, mais comprennent la possibilité d'une action analgésique non anti-inflammatoire provoquée par l'inhibition de la cyclooxygénase dans la moelle épinière et la réduction conséquente des événements rachidiens produits par la médiation des N M D A. ${ }^{14,15}$ 
Lorsqu'on les administre avant l'incision, les agonistes d'opioïdes et les anesthésiques locaux empêchent la sensibilisation centrale en atténuant le développement et le blocage de la conduction nerveuse nociceptive, respectivement. Par ailleurs, les effets analgésiques préventifs des AIN S sont de diminuer la réponse inflammatoire, réduisant ainsi la sensibilisation périphérique et ses effets sur l'action nociceptive spinale, y compris l'induction et le maintien de la sensibilisation centrale. En plus de ce mécanisme périphérique, les actions centrales des AINS peuvent aussi contribuer à l'effet analgésique préventif en empêchant la synthèse des prostanoïdes rachidiens, réduisant ainsi la libération présynaptique et postsynaptique de neurotransmetteurs (par exemple, les neuropeptides et les AAE (acides aminés excitateurs)) des terminaisons afférentes primaires et des interneurones rachidiens. L'effet combiné des deux actions serait d'empêcher ou de diminuer considérablement le développement de l'hyperexcitabilité des neurones de la corne postérieure de la moelle. Pour les patients, cela se traduit par une baisse de l'intensité de la douleur et une réduction des besoins d'analgésiques postopératoires. Ce qui veut dire que les AIN S peuvent empêcher la manifestation de différentes composantes de la douleur postopératoire (comme la sensibilisation centrale et périphérique) par plus d'un mécanisme.

Au plan de l'efficacité, l'importance des effets observés par $\mathrm{O}^{\prime} \mathrm{H}$ anlon et coll. ${ }^{13}$ a une portée clinique certaine. Comme on l'a déjà mentionné, toutefois, ces résultats contredisent la majorité des études où on a utilisé des AINS pour prévenir la douleur postopératoire. La consommation cumulative de démérol et de diclofénac a été réduite simultanément de $87 \%$ et de $50 \%$, respectivement, la différence moyenne des scores de douleur à l'EVA était de presque $1,5 \mathrm{~cm}$. Ces résultats sont particulièrement impressionnants si l'on songe que la principale différence intergroupe était le moment choisi pour l'administration du ténoxicam en rapport avec l'incision, les patients d'un groupe recevant les AIN S environ 20 min avant ceux de l'autre. $L$ 'étude présente un caractère inédit en ce que les deux groupes ont reçu du ténoxicam avant l'opération, mais l'effet analgésique préventif ne s'est manifesté que dans un seul des groupes. La différence de 20 min dans les temps d'administration a produit des effets bénéfiques qui ont duré au moins quatre heures après l'opération.

On ne pourrait s'attendre à de tels résultats si la douleur était simplement l'étape finale d'un système de transmission passive de la périphérie vers le cerveau. Sur la base des connaissances actuelles de la pharmacocinétique du ténoxicam, ${ }^{16}$ on peut penser que la dis- tribution des scores de douleur et la consommation $d$ 'analgésique seraient identiques pour les patients des deux groupes, depuis la première mesure de la douleur, 30 min après l'opération, jusqu'à la fin de I'observation de quatre heures. La mesure réalisée à 30 min correspond à environ 78 et 58 min après l'administration du ténoxicam (aux patients des deux groupes), ce qui indique qu'il s'est écoulé suffisamment de temps pour que le médicament ait pu atteindre son effet maximal. Même si les auteurs ne mentionnent que la consommation totale d'analgésiques et ne fournissent pas les données illustrant le mode de consommation pendant les quatre heures de l'étude, il est probable qu'à la mesure de 30 min les patients des deux groupes avaient déjà demandé ou reçu de l'analgésie supplémentaire. Cette consommation est fondée sur une plus basse limite de l'intervalle de confiance de $99 \%$, de 74 et 44 min respectivement pour les deux groupes au moment de la première demande d'analgésiques (calculée selon les données de la Table I). Ainsi, aussi tôt que 30 min après I'opération, avant même que l'analgésie de secours ait été administrée, la différence moyenne des scores de douleur était de $2,3 \mathrm{~cm}$. Le maintien d'une différence de douleur tout au long des quatre heures, jumelé à une plus faible consommation d'analgésiques, représente une évidence solide de l'effet analgésique préventif.

Comment se comparent les résultats de l'étude de $\mathrm{O}$ ' $\mathrm{H}$ anlon et coll. ${ }^{13}$ avec ceux d'autres études sur l'administration de AINS pour prévenir la douleur postopératoire? Sur les 18 études randomisées, à simple ou double insu, qui ont utilisé un AIN S comme intervention cible, cinq ont évalué les effets préventifs au sens large, ${ }^{17-21}$ neuf les ont évalué selon une définition stricte, ${ }^{13,22-29}$ et quatre ont tenu compte des deux types d'effets. ${ }^{30-33}$ Les études de patients qui subissent une intervention bucco-dentaire et maxillaire comme l'extraction de la troisième molaire ${ }^{17,18,20,22-25}$ ou une pulpectomie ${ }^{30}$ ont été menées les premières. Plus récemment, d'autres types d'intervention ont été étudiés, y compris I'hystérectomie abdominale, ${ }^{26,33}$ les interventions orthopédiques, ${ }^{21,27,28,31,32}$ la laparoscopie, ${ }^{19}$ et la biopsie du sein. ${ }^{13,29}$ Les médicaments ont été administrés par différentes voies : orale, rectale, intramusculaire et intraveineuse. Différents AIN S ont été utilisés, incluant les acides propioniques, les acides acétiques, les oxicams et le paracétamol qui diffèrent par l'étendue de leur activité anti-inflammatoire, les effets anal gésiques, les actions antipyrétiques et la pharmacocinétique.

Globalement, les résultats n'ont pas été encourageants. Les effets analgésiques préventifs ont été rap- 
portés dans six études ( $33 \%)$; trois d'entre elles $(\sim 16.5 \%)$ ont trouvé des effets limités ${ }^{13,29,32}$ et trois ( 16.5\%), des effets plus étendus. ${ }^{17,30,31} \mathrm{~N}$ on seulement la proportion d'études positives est-elle faible, mais l'importance des effets, lorsqu'ils sont présents, est tout au plus modeste. La seule exception vient d'une étude randomisée ${ }^{2}$ conduite dans le même établissement que celle de $\mathrm{O}^{\prime} \mathrm{H}$ anlon et coll. dans laquelle $20 \mathrm{mg}$ de ténoxicam iv ont été administrés à des femmes qui devaient subir une biopsie du sein, soit 30 min avant l'intervention, soit à un moment non spécifique après l'incision. Les patientes qui ont reçu du ténoxicam préventif ont pu attendre plus longtemps avant de prendre des analgésiques postopératoires. Elles ont eu besoin de moins de mépéridine et ont signalé des douleurs moins importantes au cours des quatre heures d'observation. L'importance de ces effets égale celle de l'étude de $\mathrm{O}^{\prime} \mathrm{H}$ anlon et coll. L'examen des données des deux études ${ }^{13,29}$ suggère que l'administration de ténoxicam à l'induction représente une intervention préchirurgicale trop tardive pour permettre l'effet analgésique préventif et n'offre aucun avantage sur l'administration post-incision.

En général, la possibilité de démontrer les effets analgésiques préventifs des AINS (vs les opiö̈des ou les anesthésiques locaux) est rendue plus difficile parce que ces agents ne bloquent pas le développement nociceptif ou la conduction nerveuse. En conséquence, les études cliniques sont inévitablement affectées par un facteur de confusion dû à la co-administration d'opioïdes à action générale et/ ou d'une infiltration d'anesthésique local à tous les patients dans le but de fournir une analgésie ou une anesthésie suffisante pendant l'intervention chirurgicale. Cette situation présente l'effet inattendu de prévenir la douleur chez les patients témoins, réduisant ainsi les différences intergroupes quant à la douleur et à la consommation d'analgésique.

Dans l'étude de $\mathrm{O}^{\prime} \mathrm{H}$ anlon et coll., ${ }^{13}$ I'administration d'alfentanil peut avoir contribué à l'analgésie préventive dans les deux groupes en réduisant la transmission afférente nocive vers la moelle épinière pendant I'opération. Les effets préventifs d'une faible dose d'alfentanil à action générale administré pendant l'opération a été reconnue comme persistant jusqu'à six heures après l'intervention ${ }^{12}$ (mais voir ${ }^{34,35}$ ). Fait plus important, l'infiltration de la plaie avec de la bupivacaïne, combinée au ténoxicam, a sans doute réduit la quantité et la nature des stimuli afférents atteignant la moelle pendant la période d'observation de quatre heures. Cette intervention, associée au ténoxicam préopératoire, a contribué aux impressionnantes dif-

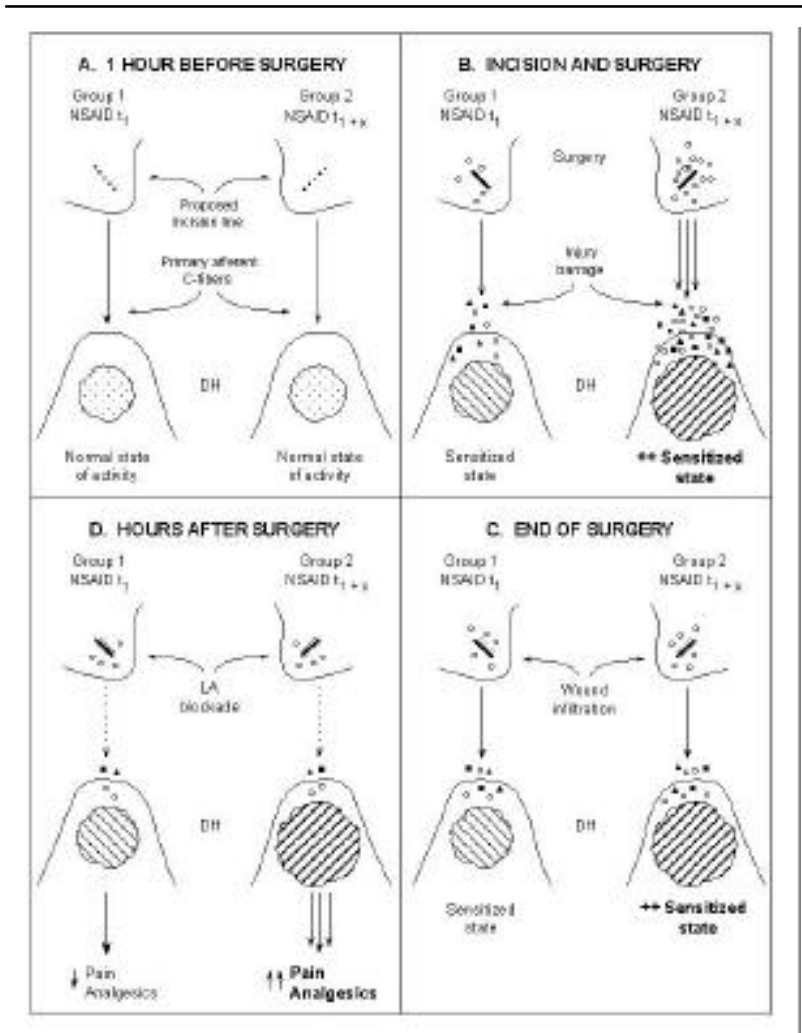

FIGU RE M odèle schématique de l'étude de deux groupes sur l'analgésie préventive selon une intervention cible avec AIN S combinée à une infiltration postopératoire de la plaie chirurgicale avec un anesthésique local. Le temps $1\left(t_{1}\right)$ correspond au temps de l'administration de l'AINS, relatif à l'incision, dans le groupe 1 . Le $t_{1}+x$ correspond au temps d'administration dans le groupe 2 . D ans l'étude de $\mathrm{O}^{\prime} \mathrm{H}$ anlon et coll., $\mathrm{t}_{1}=-30 \mathrm{~min} ; \mathrm{t}_{1}+\mathrm{x}=\sim 10 \mathrm{~min}$. A. U ne heure avant I'opération, avant toute intervention anesthésique, la corne postérieure (CP) et la périphérie présentent une activité normale. B. L'incision et les stimuli chirurgicaux nocifs subséquents induisent une sensibilisation périphérique par la médiation de l'inflammation et une sensibilisation centrale par la charge lésionnelle. Les triangles et les carrés pleins représentent les neuropeptides (par ex., la substance P (SP) et les acides aminés excitateurs ( $\mathrm{AAE}$; comme le glutamate) co-libérés à partir des terminaisons des fibres $C$ en réaction à l'intervention chirurgicale. Les cercles ouverts représentent la libération de prostaglandines au site de la lésion et dans la moelle épinière. Les prostanoïdes rachidiens peuvent pénétrer dans l'espace extracellulaire et stimuler la libération des fibres $C$ de la SP et des AAE d'après un mécanisme qui dépend du calcium. Le chronométrage de l'administration du ténoxicam amène une réduction relative, à la fois, de la sensibilisation périphérique et centrale dans le groupe 1 comparé au groupe 2. C. Au moment de l'infiltration de la plaie chirurgicale, le ténoxicam a produit une réduction de la libération de prostanoïdes dans les deux groupes, mais une sensibilisation relative induite par le traumatisme chirurgicale est maintenue. D. D ans les heures qui suivent l'opération, les actions combinées du ténoxicam (inhibition de la cascade de cyclooxygénase) et de la bupivacaïne (blocage de la conduction nerveuse) réduisent la transmission vers les neurones de la CP, empêchant ainsi une sensibilisation plus ample. L'effet net de l'élévation de la sensibilisation dans le groupe 2 est d'amplifier les signaux périphériques et centraux conduisant à une douleur plus intense et à un accroissement des besoins d'analgésie postopératoire par rapport au groupe 1 . $N$ otez que les événements neurochimiques décrivant les processus périphérique et central qui suivent la lésion ont été simplifiés. 
férences de douleur et de consommation d'analgésiques (Figure 1). Pour d'autres études, l'impossibilité de démontrer l'effet analgésique préventif a été attribuée à une sensibilisation centrale induite par l'inflammation qui s'est développée peu après I'opération, une fois que l'action pharmacologique du médicament préopératoire avait cessé, ou à un blocage afférent inadéquat après l'intervention. ${ }^{36} \mathrm{~L}$ 'hydre du problème, ${ }^{37}$ ainsi nommé d'après le serpent mythique à sept têtes à qui il poussait deux têtes chaque fo is qu' on en coupait une, a fourni l'élan nécessaire pour l'utilisation des médicaments dont la durée d'action s'étendait à la période postopératoire. ${ }^{38} \mathrm{D}$ ans l'étude de $\mathrm{O}$ ' $\mathrm{H}$ anlon et coll., ${ }^{13}$ la réduction de l'activité nociceptrice périphérique et l'inflammation causée par l'action combinée de l'infiltration de bupivacaïne dans la plaie et de l'administration iv préopératoire de ténoxicam semble avoir été suffisante pour inhiber la sensibilisation ultérieure au début de la période postopératoire. C ela a eu pour effet de dévoiler la plus grande sensibilisation centrale relative, induite par l'incision, et les stimuli peropératoires nocifs subséquents chez les patients qui ont reçu le ténoxicam à l'induction (Figure 1). II est intéressant de noter que deux études seulement ${ }^{13,29}$ ont combiné l'administration préopératoire d'un AINS et l'infiltration postopératoire de la plaie avec un anesthésique local et les deux études ont démontré des réductions notables de la douleur et de la consommation d'analgésique.

Ensemble, ces résultats ${ }^{13,29}$ se démarquent nettement de l'absence d'effets cliniques significatifs d'autres études dans lesquelles les AIN S sont utilisés pour prévenir la douleur postopératoire. Qu'une lésion provoque une sensibilisation périphérique et centrale, c'est bien établi. L'est également la capacité des AINS à prévenir ou à renverser ces états anormaux. O'Hanlon et coll. semblent avoir trouvé la bonne combinaison de facteurs pour démontrer un effet analgésique préventif; à savoir, l'administration iv préopératoire de ténoxicam, une intervention de courte durée, le dommage tissulaire transmis principalement par les fibres afférentes so matiques, l'infiltration postchirurgicale d'un anesthésique local à action prolongée et l'évaluation de la douleur et de la consommation d'analgésiques au début de la période postopératoire.

\section{Remerciements}

L'étude a été réalisée grâce au soutien accordé par les subventions MCT-38144 et MOP-37845 des Instituts de recherche en santé du Canada (IRSC) et d'une Bourse scientifique de I'IRSC.

\section{References}

1 Melzack R, Wall PD. The Challenge of Pain, 2nd ed. N ew York: Basic Books, 1988.

2 Coderre TJ, Katz J, Vaccarino A L, M elzack R. Contribution of central neuroplasticity to pathological pain: review of clinical and experimental evidence. Pain 1993; 52: 259-85.

$3 \mathrm{~K}$ atz J, K avanagh BP, Sandler A N, et al. Preemptive analgesia. Clinical evidence of neuroplasticity contributing to postoperative pain. Anesthesiology 1992; 77: 439-46.

4 Cousins MJ, Power I, Smith G 1996 Labat Lecture: pain - a persistent problem. Reg Anesth Pain M ed 2000; 25: 6-21.

$5 \mathrm{Kissin} \mathrm{I.} \mathrm{Preemptive} \mathrm{analgesia:} \mathrm{how} \mathrm{can} \mathrm{we} \mathrm{make} \mathrm{it}$ work? I n: D evor M, Rowbotham M, Wiesenfeld-H allin $Z$ (Eds.). Proceedings of the 9 th World Congress on Pain, Progress in Pain Research and $\mathrm{M}$ anagement, $\mathrm{Vol}$. 17. Seattle: IASP Press, 2000: 973-85.

$6 \mathrm{~K}$ atz J. Preemptive analgesia: where do we go from here? The Journal of Pain 2000; 1: 89-92.

7 Taylor BK, Brennan TJ. Preemptive analgesia: moving beyond conventional strategies and confusing terminology. The J ournal of Pain 2000; 1: 77-84.

$8 \mathrm{~K}$ atz J. George Washington Crile, anoci-association and pre-emptive analgesia. Pain 1993; 53: 243-5.

9 Wall PD. The prevention of postoperative pain (Editorial). Pain 1988; 33: 289-90.

10 R undshagen I, K ochsE, Schulte am Esch J. Surgical stimulation increases median nerve somatosensory evoked responses during isoflurane-nitrous oxide anaesthesia. Br J Anaesth 1995; 75: 598-602.

11 A bram SE, Yaksh TL. M orphine, but not inhalation anesthesia, blocks post-injury facilitation. The role of preemptive suppression of afferent transmission. Anesthesiology 1993; 78: 713-21.

$12 \mathrm{~K}$ atz J, Clairoux M, R edahan C, et al. $\mathrm{H}$ igh dose alfentanil pre-empts pain after abdominal hysterectomy. Pain 1996; 68: 109-18.

13 O'H anlon D, Thambipillai T, Colbert ST, Keane PW, Given $\mathrm{FH}$. Timing of pre-emptive tenoxicam is important for postoperative analgesia. Can J Anesth 2001; 48: 162-66.

14 Yaksh TL, Dirig D M, M almberg A B. M echanism of action of nonsteroidal anti-inflammatory drugs. $C$ ancer Invest 1998; 16: 509-27.

15 Malmberg A B, Yaksh TL. H yperalgesia mediated by spinal glutamate or substance $P$ receptor blocked by spinal cyclooxygenase inhibition. Science 1992; 257: 1276-9.

$16 \mathrm{~N}$ ilsen OG. Clinical pharmacokinetics of tenoxicam. Clin Pharmacokinet 1994; 26: 16-43.

17 Campbell WI, K endrick R, Patterson C. Intravenous diclofenac sodium. D oes its administration before oper- 
ation suppress postoperative pain? Anaesthesia 1990; 45: 763-6.

18 H utchison GL, Crofts SL, Gray IG. Preoperative piroxicam for postoperative analgesia in dental surgery. $\mathrm{Br} \mathrm{J}$ Anaesth 1990; 65: 500-3.

19 C rocker S, Paech M. Preoperative rectal indomethacin for analgesia after laparoscopic sterilisation. Anaesth Intensive Care 1992; 20: 337-40.

20 Smith A C, Brook I M. I nhibition of tissue prostaglandin synthesis during third molar surgery: use of preoperative fenbufen. Br J O ral M axillofac Surg 1990; 28: 251-3.

21 M orrow BC, Milligan KR, M urthy BV. Analgesia following day-case knee arthroscopy-the effect of piroxicam with or without bupivacaine infiltration. Anaesthesia 1995; 50: 461-3.

22 Gustafsson I, N ystrom E, Quiding H. Effect of preoperative paracetamol on pain after oral surgery. Eur J Clin Pharmacol 1983; 24: 63-5.

23 Sisk A L, Mosley R O, Martin R P. Comparison of preoperative and postoperative diflunisal for suppression of postoperative pain. J O ral M axillofac Surg 1989; 47: 464-8.

24 Sisk A L, Grover BJ . A comparison of preoperative and postoperative naproxen sodium for suppression of postoperative pain. J O ral M axillofac Surg 1990; 48: 674-8.

25 Bridgman JB, Gillgrass TG, Zacharias M. The absence of any pre-emptive analgesic effect for non-steroidal anti-inflammatory drugs. Br J O ral M axillofac Surg 1996; 34: 428-31.

26 Espinet $A, H$ enderson $D J$, Faccenda $K A$, M orrison $L M$. $D$ oes pre-incisional thoracic extradural block combined with diclofenac reduce postoperative pain after abdominal hysterectomy? Br J Anaesth 1996; 76: 209-13.

$27 \mathrm{~N}$ orris A, Un V, Katz J, et al. Do N SAIDS have a preemptive analgesic effect? A randomized, double-blind, placebo-controlled clinical trial. Can J Anaesth 1995; 42: 37-A.

28 Vanlersberghe C, Lauwers M H , Camu F. Preoperative ketorolac administration has no preemptive analgesic effect for minor orthopaedic surgery. Acta Anaesthesiol Scand 1996; 40: 948-52.

29 Colbert ST, O'H anlon DM, M CD onnell C, Given FH, $\mathrm{K}$ eane PW. Analgesia in day case breast biopsy - the value of pre-emptive tenoxicam. Can J Anaesth 1998; 45: 217-22.

30 Flath RK, H icks ML, Dionne R A, Pelleu GB Jr. Pain suppression after pulpectomy with preoperative flurbiprofen. J Endod 1987; 13: 339-47.

31 Bunemann $L$, Thorshauge $H, H$ erlevsen $P, I$ versen $A D$, $\mathrm{N}$ ielsen $\mathrm{FB}$. A nalgesia for outpatient surgery: placebo versus naproxen sodium (a non-steroidal anti-inflam- matory drug) given before or after surgery. Eur J Anaesthesiol 1994; 11: 461-4.

32 Fletcher D, Zetlaoui $P$, M onin S, Bombart M, Samii K. Influence of timing on the analgesic effect of intravenous ketorolac after orthopedic surgery. Pain 1995; 61: 291-7.

33 R ogers JE, Fleming BG, Macintosh K C, J ohnston B, $M$ organ-H ughesJO. E ffect of timing of ketorolac administration on patient-controlled opioid use. $\mathrm{Br}$ J Anaesth 1995; 75: 15-8.

34 Eisenach JC. Preemptive hyperalgesia, not analgesia? (Editorial). Anesthesiology 2000; 92: 308-9.

35 Celerier $E, R$ ivat $C$, J un $Y$, et al. Long-lasting hyperalgesia induced by fentanyl in rats: preventive effect of ketamine. Anesthesiology 2000; 92: 465-72.

36 Dahl JB. Neuronal plasticity and pre-emptive analgesia: implications for the management of postoperative pain. Dan Med Bull 1994; 41: 434-42.

37 N iv D, Lang E, D evor $M$. The effect of preemptive analgesia on subacute postoperative pain. $M$ inerva Anestesiol 1999; 65: 127-41.

38 K issin I, LeeSS, Bradley EL J r. Effect of prolonged nerve block on inflammatory hyperalgesia in rats: prevention of late hyperalgesia. Anesthesiology 1998; 88: 224-32. 